\title{
Anti-inflammatory and antioxidant effects of MOK, a polyherbal extract, on lipopolysaccharide-stimulated RAW 264.7 macrophages
}

\author{
JI HYE HWANG ${ }^{1}$, JUN NAN MA ${ }^{2}$, JONG HUN PARK ${ }^{2}$, HYO WON JUNG ${ }^{2}$ and YONG-KI PARK ${ }^{2}$ \\ ${ }^{1}$ Department of Acupuncture and Moxibustion Medicine, College of Korean Medicine, Gachon University, \\ Seongnam, Gyeonggi 13120; ${ }^{2}$ Department of Herbology, College of Korean Medicine, \\ Dongguk University, Gyeongju, North Gyeongsang 38066, Republic of Korea
}

Received July 20, 2018; Accepted October 15, 2018

DOI: $10.3892 /$ ijmm.2018.3937

\begin{abstract}
MOK, a pharmacopuncture medicine consisting of 10 herbs, has a long history as treatment for various inflammatory conditions. To investigate the mechanisms of action of MOK, its anti-inflammatory and antioxidative effects were assessed in RAW 264.7 macrophages stimulated by lipopolysaccharide (LPS). RAW 264.7 cells were treated with different concentrations of MOK extract for $30 \mathrm{~min}$ prior to stimulation with or without LPS for the indicated times. Nitric oxide (NO) production was measured using Griess reagent, while the mRNA levels of inflammatory cytokines, tumor necrosis factor (TNF)- $\alpha$, interleukin (IL)-1 $\beta$, IL-6 and the antioxidant enzymes Mn superoxide dismutase and heme oxygenase-1, were determined using reverse transcription-polymerase chain reaction analysis. Western blotting was used to determine the protein expression of inducible nitric oxide synthase (iNOS), cyclooxygenase (COX)-2, superoxide dismutase (SOD)2, catalase (CAT) and heme oxygenase-1 (HO-1), and the phosphorylation of mitogen-activated protein kinases (MAPKs), including ERK1/2, JNK and p38. Western blotting and immunocytochemistry were used to observe the nuclear expression

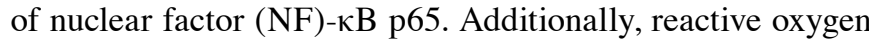
species (ROS) and prostaglandin $(\mathrm{PG}) \mathrm{E}_{2}$ production were determined using the ROS assay and an enzyme immunoassay. With MOK treatment, there was a notable decrease in $\mathrm{NO}$ and $\mathrm{PGE}_{2}$ production induced by LPS in RAW 264.7 cells by downregulation of iNOS and COX-2 mRNA and protein expression. Furthermore, with MOK treatment, there was a decrease in the mRNA expression levels of TNF- $\alpha$, IL-1 $\beta$ and IL-6, as well as in the phosphorylation of ERK, JNK and
\end{abstract}

Correspondence to: Dr Yong-Ki Park, Department of Herbology, College of Korean Medicine, Dongguk University, Gyeongju, North Gyeongsang 38066, Republic of Korea

E-mail: yongki@dongguk.ac.kr

Key words: MOK, pharmacopuncture, anti-inflammatory activity, antioxidative activity, RAW 264.7 macrophage, lipopolysaccharide p38 MAPK, by blocking the nuclear translocation of NF- $\kappa \mathrm{B}$ p65 in LPS-stimulated cells. In addition, MOK treatment led to an increase in the antioxidant enzymes SOD, CAT and HO-1 in LPS-stimulated cells, with a concomitant decrease in ROS generation. These results indicate that the inflammatory responses in activated macrophages are inhibited by MOK through downregulation of the transcription levels of inflammatory mediators and inhibition of the MAPK/NF- $\kappa \mathrm{B}$ pathway. Moreover, MOK protects against oxidative damage by upregulating the expression of antioxidant enzymes and generating ROS scavengers.

\section{Introduction}

Macrophages play important roles in the host immune defense system during infection and disease development; their activation by different stimuli, including bacterial lipopolysaccharide (LPS) $(1,2)$, causes production of pro-inflammatory cytokines [tumor necrosis factor (TNF)- $\alpha$, interleukin (IL)-1 $\beta$ and IL-6], inflammatory mediators [nitric oxide (NO), prostaglandin (PG) $\mathrm{E}_{2}$ ], and reactive oxygen species (ROS), which contribute to the progression of several inflammatory diseases (3). In turn, the inflammatory burden of ROS is increased by the formation of reactive nitrogen species (RNS) from the rapid combination of NO with superoxide radical-induced nitrosative stress. Therefore, an imbalanced redox milieu may result from either or both overproduction of ROS and decreased antioxidant capacity (2). It is well-known that useful therapeutic strategies for various inflammatory diseases include the control of production of free radicals and inflammatory mediators.

In complementary and alternative medicine, diseases are considered to represent an imbalance between Yin and Yang. In traditional Chinese medicine and traditional Korean medicine (TKM), various treatment methods, including acupuncture, pharmacopuncture and herbal medicines, are used to rebalance the Yin and Yang of individual patients; in particular, the mechanism underlying their therapeutic effect has been reported to be associated with anti-inflammatory and immunomodulatory responses.

A growing body of scientific evidence supports acupuncture as an effective treatment of various inflammatory 
conditions in several diseases $(4,5)$. Recent studies have reported on the mediation of the anti-inflammatory and immunomodulatory effects of acupuncture by the downregulation of pro-inflammatory cytokines, including TNF- $\alpha$, IL-1 $\beta$, IL-6, IL-8 and IL-10, along with C-reactive protein, erythrocyte sedimentation rate, and the modulation of immunoglobulin (Ig) $\mathrm{M}$ and IgA in chronic obstructive pulmonary disease, spastic cerebral palsy and periodontitis, as well as in clinical studies of rheumatoid arthritis and acute pancreatitis (4,6-10).

Pharmacopuncture therapy, which includes stimulating acupoints along with the injection at the acupoints of herbal extracts, is a new form of acupuncture applied in TKM. This therapy is commonly used to regulate immune imbalance in the clinical setting and is considered as a good candidate for the treatment of inflammatory diseases. Among pharmacopuncture medicines, MOK is used for the clinical treatment of the fire meridians and symptoms related to diseases of the heart and thyroid gland. It is also used for a Korean somatization disorder, Hwa-Byung, which is a mental illness associated with the inability to control anger (11). MOK, a pharmacopuncture medicine consisting of ten herbs, is used to treat these conditions due to its anti-inflammatory and antioxidant properties, in addition to its immunomodulatory functions (12-14). Specifically, MOK has been reported to exert anti-inflammatory effects in cell-based assays (14). Moreover, its in vivo anti-hypothyroidism and anti-hyperthyroidism effects have been confirmed in previous studies $(15,16)$. In addition, its inhibitory function on the production of inflammatory mediators by primary peritoneal macrophages has been reported (17). However, there is little scientific evidence regarding the efficacy of MOK therapy in inflammation.

The aim of the present study was to investigate the anti-inflammatory and antioxidant effects of MOK on RAW264.7 macrophages stimulated by LPS and identify the mechanism responsible for these effects on signaling pathways.

\section{Materials and methods}

Reagents. The present study used Dulbecco's modified Eagle's medium (DMEM) obtained from Invitrogen; Thermo Fisher Scientific (Carlsbad, CA, USA) supplemented with 10\% fetal bovine serum (FBS; Invitrogen; Thermo Fisher Scientific), $2 \mathrm{~mm}$ L-glutamine (Invitrogen; Thermo Fisher Scientific), and $0.1 \mathrm{~mm}(0.7 \mu 1 / 100 \mathrm{ml}$ final media volume) 2-mercaptoethanol (Sigma-Aldrich; Merck KGaA, St. Louis, MO, USA). LPS (Isotype 055:B5), sulphanilamide, dimethyl sulphoxide and $\mathrm{N}$-(1-napthyl)ethylenediamine dihydrochloride (NED) were purchased from Sigma-Aldrich; Merck KGaA. Penicillin and streptomycin were obtained from GenDEPOT (Barker, TX, USA). The WST-1-based cell cytotoxicity assay kit was obtained from Roche Diagnostics GmbH (Mannheim, Germany). Primary monoclonal antibodies against iNOS (1:200, cat. no. 13120, Cell Signaling Technology, Danvers, MA, USA), NF-кB (1:200, sc-109, Santa Cruz Biotechnology, Dallas, TX, USA), TBP (1:200, sc-273, Santa Cruz Biotechnology), $\beta$-actin (1:2,000, cat. no. A-5316-2ML, Sigma-Aldrich; Merck KGaA), ERK1/2 (1:200, cat. no. 9102, Cell Signaling Technology), JNK (1:200, cat. no. 9252, Cell Signaling Technology), p38 (1:200, cat. no. 9212, Cell Signaling Technology) MAPKs and their phosphorylated forms (1:200, cat. no. 9101 for p-ERK, cat. no. 9251 for p-JNK, and cat. no. 9211 for p-p38), superoxide dismutase (SOD) 2 (1:1,000, cat. no. 13141, Cell Signaling Technology), catalase (CAT; 1:1,000, cat. no. 14097, Cell Signaling Technology), and COX-2 (1:1,000, cat no. sc-7951, Santa Cruz Biotechnology) were used. Goat anti-mouse $(1: 2,000$, cat. no. 1721011, Bio-Rad Laboratories, Hercules, CA, USA) or rabbit IgE $(\mathrm{H}+\mathrm{L})$-horseradish peroxidase-conjugated secondary antibody (1:2,000, cat. no. 1721019, Bio-Rad Laboratories) were used. All other chemicals were purchased from Sigma-Aldrich; Merck KGaA, the Taq-based PCR enzyme was supplied by Toyobo (Osaka, Japan), and the OxiSelect in vitro ROS/RNS assay kit was obtained from Cell Biolabs (San Diego, CA, USA).

MOK extract preparation. The MOK extract, a prescription containing ten herbs (Table I), was obtained in a sealing vial $(53.1 \mathrm{mg} / \mathrm{ml})$ from Namsangcheon Herbal Medicine Dispensary, an extramural facility meeting the Korean Good Manufacturing Practice standards. All raw materials of MOK were authenticated by the Korean Food and Drug Administration.

Cell culture. RAW 264.7 cells, a mouse macrophage cell line obtained from the American Type Culture Collection (Manassas, VA, USA), were maintained in DMEM supplemented with 10\% FBS (HyClone; GE Healthcare Life Sciences, Logan, UT, USA), $100 \mathrm{U} / \mathrm{ml}$ penicillin and $100 \mu \mathrm{g} / \mathrm{ml}$ streptomycin at $37^{\circ} \mathrm{C}$ in a $5 \% \mathrm{CO}_{2}$ incubator.

Cell viability assay. The commercially available WST-1 cell viability assay kit was employed to evaluate the cytotoxic effects of MOK extract in accordance with the manufacturer's protocol. Briefly, RAW 264.7 cells $\left(5 \times 10^{4}\right)$ were seeded into 96-well microtiter plates (Nunc, Roskillde, Denmark) with different concentrations of MOK extract and cultured for $24 \mathrm{~h}$ at $37^{\circ} \mathrm{C}$ in an incubator with $5 \% \mathrm{CO}_{2}$. The WST-1 reagent was added to each well at the end of the treatment, and the plates were incubated for a further $2 \mathrm{~h}$. Finally, absorbance was measured at $450 \mathrm{~nm}$ with a microtiter plate reader (Asys, Cambridge, England).

NO level measurement. RAW 264.7 cells $\left(1 \times 10^{5}\right.$ cells $\left./ \mathrm{ml}\right)$ were pretreated with various concentrations of MOK extract for $30 \mathrm{~min}$ and then stimulated for $24 \mathrm{~h}$ with or without $1 \mu \mathrm{g} / \mathrm{ml}$ LPS at $37^{\circ} \mathrm{C}$ in an incubator with $5 \% \mathrm{CO}_{2}$. The $\mathrm{NO}$ level in the culture supernatants was measured using Griess reagents by adding $50 \mu \mathrm{l} 1 \%$ sulphanilamide and $50 \mu \mathrm{l} 0.1 \%$ NED in $5 \%$ phosphoric acid to $100 \mu \mathrm{l}$ of culture supernatant in each well and incubating at room temperature for $15 \mathrm{~min}$ in the dark. Subsequently, absorbance at $540 \mathrm{~nm}$ was measured with a Spectramax 250 microplate reader (GENios; Tecan, Männedorf, Switzerland). A standard curve was prepared using $\mathrm{NaNO}_{2}$ as a standard solution in the same manner, and was used to calculate the concentration of NO.

$P G E_{2}$ level measurement. RAW 264.7 cells were pretreated with various concentrations of MOK extract for $30 \mathrm{~min}$ followed by stimulation with or without LPS for $18 \mathrm{~h}$ at $37^{\circ} \mathrm{C}$ in an incubator with $5 \% \mathrm{CO}_{2}$. $\mathrm{PGE}_{2}$ levels were assessed by 
Table I. Constituents of MOK extract.

\begin{tabular}{llc}
\hline Herbal name & Scientific name & $\begin{array}{c}\text { Content } \\
(\mathrm{mg} / \mathrm{ml})\end{array}$ \\
\hline Hominis Placenta & $\begin{array}{l}\text { Hominis Placenta } \\
\text { Moschus }\end{array}$ & 2 \\
Fel Ursi & Ursus arctos & 0.5 \\
Calculus Bovis Cow & Bos taurus & 0.3 \\
bezoar & & 0.3 \\
Scutellariae Radix & Scutellaria baicalensis & 10 \\
Phellodendri Cortex & Phellodendron amurense & 10 \\
Pulsatilla Koreana & Pulsatilla koreana & 10 \\
Sophorae Subprostratae & Sophora tonkinensis & 10 \\
Radix & & \\
Aucklandiae Radix & Aucklandia lappa & 5 \\
Aquilaria agallocha & Aquilaria agallocha & 5 \\
& Total & 53.1
\end{tabular}

a commercially available $\mathrm{PGE}_{2}$ enzyme immunoassay kit (Cayman Chemical Co., Ann Arbor, MI, USA) in accordance with the instructions of the manufacturer. The $\mathrm{PGE}_{2}$ concentration was analyzed in accordance with the formula obtained from the standard curve generated using the $\mathrm{PGE}_{2}$ standard solution provided in the kit.

Reverse transcription-polymerase chain reaction (RT-PCR) analysis. RAW 264.7 cells were pretreated with various concentrations of $\mathrm{MOK}$ extract for $30 \mathrm{~min}$ prior to incubation for $5 \mathrm{~h}$ at $37^{\circ} \mathrm{C}$ in an incubator with $5 \% \mathrm{CO}_{2}$, with or without LPS. Total RNA was extracted from the cells using TRIzol reagent (Gibco-BRL Life Technologies; Thermo Fisher Scientific, Inc., Waltham, MA, USA) and used for cDNA synthesis along with an oligo-dT primer, ImProm-II reverse transcriptase (2 U), $0.5 \mathrm{mM}$ dNTP, $3 \mathrm{mM} \mathrm{MgCl}_{2}$, and RNase inhibitor in 5X Reverse Transcriptase Buffer (Promega Co., Madison, WI, USA). cDNA was synthesized at $25^{\circ} \mathrm{C}$ for $5 \mathrm{~min}$ and $42^{\circ} \mathrm{C}$ for $60 \mathrm{~min}$. PCR was performed with the incubation mixture [2 $\mu \mathrm{l}$ cDNA, $4 \mu \mathrm{M} 5^{\prime}$ and $3^{\prime}$ specific primers (Table II), 10X buffer (10 mM Tris- $\mathrm{HCl}, \mathrm{pH} 8.3,50 \mathrm{mM} \mathrm{KCl}$, $25 \mathrm{mM} \mathrm{MgCl}_{2}, 0.1 \%$ Triton X-100, $250 \mu \mathrm{M} \mathrm{dNTP}$, and $1 \mathrm{U}$ Taq polymerase (TaKaRa Bio Inc., Shiga, Japan)] under the following conditions: $30 \mathrm{sec}$ at $94^{\circ} \mathrm{C}$ (denaturation), $30 \mathrm{sec}$ at $60^{\circ} \mathrm{C}$ (annealing), $1 \mathrm{~min}$ for extension, and a final extension for $10 \mathrm{~min}$ at the end of 35 cycles. The band intensities were quantified by densitometric analysis (ChemiDoc MP Imaging System; Bio-Rad Laboratories) and were expressed relative to the intensity of the GAPDH band.

Western blot analysis. RAW 264.7 cells were pretreated for 30 min with MOK extract at various concentrations, followed by stimulation with or without LPS for $24 \mathrm{~h}$ (in the case of iNOS, COX-2, SOD2 and CAT), for $30 \mathrm{~min}$ (in the case of $\mathrm{NF}-\kappa \mathrm{B}, \mathrm{I}-\kappa \mathrm{B}, \mathrm{JNK}$, and $\mathrm{p} 38 \mathrm{MAPK}$ ), or for $5 \mathrm{~min}$ (in the case of ERK MAPK) at $37^{\circ} \mathrm{C}$ in a $5 \% \mathrm{CO}_{2}$ incubator. The cells were lysed by adding $0.1 \mathrm{ml} 50 \mathrm{~mm}$ Tris- $\mathrm{HCl}$ ( $\mathrm{pH} 7.2)$, including $0.1 \%$ sodium dodecyl sulphate, $1 \%$ sodium deoxycholate, $1 \%$
NP-40 and 0.15 M NaCl. Nuclear extracts were prepared using the NE-PER Nuclear and Cytoplasmic Extraction Kit (Pierce Biotechnology Inc., Rockford, IL, USA) in accordance with the manufacturer's instructions, and the protein concentration was determined using the Bradford assay. Equal amounts of protein $(20 \mu \mathrm{g} / \mathrm{ml})$ were electrophoresed on $10 \%$ sodium dodecyl sulfate-polyacrylamide gels. After electrophoresis, an electric transfer system was used to transfer proteins from the gel onto a nitrocellulose membrane. Non-specific binding was blocked with $3 \%$ skimmed milk in TBST buffer $(5 \mathrm{~mm}$ Tris-HCl, pH 7.6, $136 \mathrm{~mm} \mathrm{NaCl}$ and $0.1 \%$ Tween-20) for $1 \mathrm{~h}$. The blots were then incubated for $1 \mathrm{~h}$ at room temperature with primary antibodies against iNOS, COX-2, $\beta$-actin, all forms of ERK1/2, JNK, p38 and their phosphorylated forms, SOD2, CAT, p65 NF- $\kappa \mathrm{B}$, or I- $\kappa \mathrm{B}$, and washed three times with $1 \mathrm{X}$ TBST. The blots were incubated for $1 \mathrm{~h}$ at room temperature with horseradish peroxidase-labeled anti-mouse IgG (Santa Cruz Biotechnology), washed with 1X TBST three times and developed using ECL western blotting detection reagents (GE Healthcare Bio-Sciences, Pittsburgh, PA, USA) prior to analysis with a ChemiDoc MP Imaging System (Bio-Rad Laboratories). The intensity of western blot bands was quantified and values were expressed relative to that of $\beta$-actin or total forms of the MAPKs.

Immunocytochemistry. To confirm the nuclear translocation of $\mathrm{NF}-\kappa \mathrm{B}$, cells were seeded in four-well slide chambers and pretreated with MOK extract at various concentrations with or without LPS $(1 \mu \mathrm{g} / \mathrm{ml})$ for $2 \mathrm{~h}$. The cells were washed twice with $1 \mathrm{X}$ PBS and fixed with $1 \%$ paraformaldehyde for $15 \mathrm{~min}$, followed by blocking with $1 \%$ bovine serum albumin in PBST to reduce non-specific immunoreactivity. The cells were then incubated overnight with anti-NF- $\kappa$ B p65 antibody at $4^{\circ} \mathrm{C}$, washed three times with $1 \mathrm{X}$ PBS, and incubated with goat anti-rabbit Alexa Fluor 488 (green)-labelled secondary antibody (Abcam, Cambridge, UK) for $2 \mathrm{~h}$ at room temperature in the dark. The stained cells were washed with $1 \mathrm{X}$ PBS and then mounted with fluorescence mounting medium containing 4',6-diamidino-2-phenylindole (DAPI). Next, the fluorescent-stained cells were examined under a fluorescence microscope (Leica, Solms, Germany) at a magnification of $\mathrm{x} 200$.

Intracellular ROS measurement. RAW 264.7 cells $\left(5 \times 10^{5}\right.$ cells $\left./ \mathrm{ml}\right)$ were pre-incubated for $20 \mathrm{~h}$, followed by incubation with or without MOK extract $(2.5,5$ or $10 \mathrm{mg} / \mathrm{ml})$ with or without LPS for $24 \mathrm{~h}$. The ROS levels were then analyzed using an OxiSelect in vitro ROS/RNS assay kit (Cell Biolabs) based on the conversion of 2',7',7-diacetate to 2',7'dichlorodihydrofluorescein by ROS. The cells were homogenized, and the fluorescence spectrum (excitation: $480 \mathrm{~nm}$, emission: $530 \mathrm{~nm}$ ) was measured with a fluorescence plate reader (LS 55 Luminescence spectrometer; Perkin Elmer, Wellesley, MA, USA).

Statistical analysis. GraphPad Prism (GraphPad Software, Inc., San Diego, CA, USA) was used for the statistical analyses. The data were summarized as means \pm standard error of the mean of three independent experiments and analyzed by one-way analysis of variance followed by Tukey's post hoc 
Table II. Primers for PCR analysis.

\begin{tabular}{lll}
\hline Name & \multicolumn{1}{c}{ Forward $\left(5^{\prime} \rightarrow 3^{\prime}\right)$} & \multicolumn{1}{c}{ Reverse $\left(5^{\prime} \rightarrow 3^{\prime}\right)$} \\
\hline iNOS & GGTGTTGAAGGCGTAGCTGA & ATCATGGACCACCACACAGC \\
COX-2 & ATGCTCCTGCTTGAGTATGT & CACTACATCCTGACCCACTT \\
IL- $\beta$ & ATGGCAACTGTTCCTGAACTCAACT & CAGGACAGGTATAGATTCTTTCCTTT \\
IL-6 & GAGGATACCACTCCCAACAGACC & TTCACAGAGGATACCACTCC \\
TNF- $\alpha$ & AGCCCCCAGTCTGTATCCTT & CTCCCTTTGCAGAACTCAGG \\
MnSOD & GTGACTTTGGGTCTTTTGA & GCTAACATTCTCCCAGTT \\
HO- 1 & AAGATTGCCCAGAAAGCCCTGGAC & AACTGTCGCCACCAGAAAGCTGAG \\
GAPDH & GACATCATACTTGGCAGG & CTCGTGGAGTCTACTGGT
\end{tabular}

PCR, polymerase chain reaction; iNOS, inducible nitric oxide synthase; COX, cyclooxygenase; IL, interleukin; TNF, tumor necrosis factor; SOD, superoxide dismutase; HO-1, heme oxugenase-1; GAPDH, glyceraldehyde 3-phosphate dehydrogenase.

test (a null hypothesis of no difference was rejected with a P-value <0.05).

\section{Results}

Effect of MOK on cell viability. The cytotoxic effects of MOK extract were investigated by measuring cell viability using the WST-1 assay. Treatment of RAW 264.7 cells stimulated by LPS with MOK extract at a concentration of $10 \mathrm{mg} / \mathrm{ml}$ exerted no effect on cell viability (Fig. 1). Therefore, MOK extract was used at concentrations of $2.5-10 \mathrm{mg} / \mathrm{ml}$ to investigate its effects on inflammation induced by LPS in RAW 264.7 cells.

Effects of MOK on NO production and iNOS expression. The inhibitory effect of MOK extract on pro-inflammatory mediator production was investigated by measuring NO levels and iNOS expression in RAW 264.7 cells stimulated by LPS. NO production (Fig. 2A) and iNOS expression at the mRNA (Fig. 2B) and protein (Fig. 2C) levels exhibited a statistically significant $(\mathrm{P}<0.05, \mathrm{P}<0.01$ and $\mathrm{P}<0.01$, respectively) increase following stimulation of the cells by LPS. Ttreatment with MOK extract at concentrations of 2.5, 5 and $10 \mathrm{mg} / \mathrm{ml}$ achieved a statistically significant decrease $(\mathrm{P}<0.05)$ of NO production in cells stimulated by LPS, in a dose-dependent manner. Moreover, treatment with $10 \mathrm{mg} / \mathrm{ml}$ MOK extract achieved a statistically significant inhibition of iNOS expression at the mRNA (Fig. 2B) and protein (Fig. 2C) levels $(\mathrm{P}<0.01$ and $\mathrm{P}<0.05$, respectively) in cells stimulated by LPS, indicating that MOK extract inhibited NO production by downregulating iNOS transcription in the activated macrophages.

Effects of $M O K$ extract on $P G E_{2}$ production and $C O X-2$ expression. Next, the inhibitory effects of MOK extract on $\mathrm{PGE}_{2}$ production and COX-2 expression were examined in RAW 264.7 cells stimulated by LPS. $\mathrm{PGE}_{2}$ production (Fig. 3A) and COX-2 expression at the mRNA (Fig. 3B) and protein (Fig. 3C) levels exhibited a statistically significant increase $(\mathrm{P}<0.001, \mathrm{P}<0.01$ and $\mathrm{P}<0.05$, respectively) following stimulation of the cells by LPS. Treatment of RAW 264.7 cells with MOK extract at concentrations of $2.5,5$ and $10 \mathrm{mg} / \mathrm{ml}$ achieved a statistically significant decrease $(\mathrm{P}<0.05, \mathrm{P}<0.01$ and $\mathrm{P}<0.001$, respectively) in LPS-induced $\mathrm{PGE}_{2}$ production

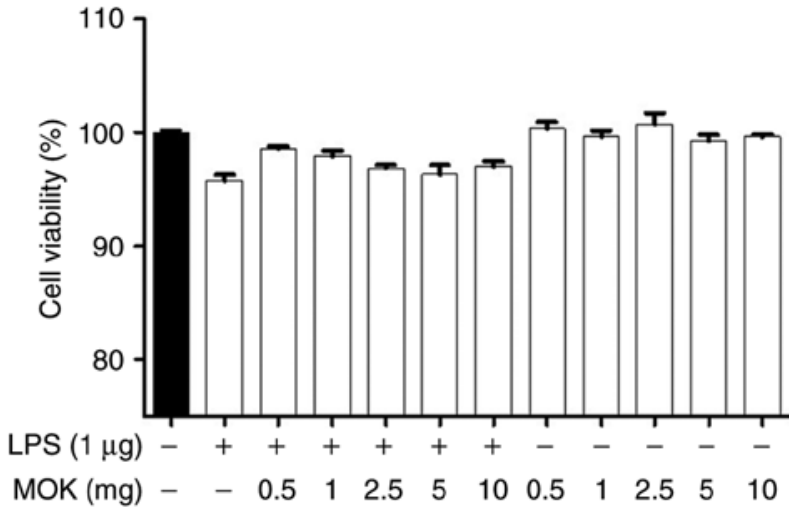

Figure 1. Cytotoxic effects of MOK extract on RAW 264.7 cells. Different concentrations of MOK $(0.5-10 \mathrm{mg} / \mathrm{ml})$ were used for cell treatment for $24 \mathrm{~h}$, with or without LPS $(1 \mu \mathrm{g} / \mathrm{ml})$. WST-1 assay was used to determine cell viability. Values are shown as means \pm standard error of the mean. LPS, lipopolysaccharide.

in a concentration-dependent manner (Fig. 3A). MOK extract $(10 \mathrm{mg} / \mathrm{ml})$ also achieved a statistically significant inhibition of COX-2 mRNA (Fig. 3B) and protein (Fig. 3C) expression $(\mathrm{P}<0.05$ and $\mathrm{P}<0.01$, respectively) in cells stimulated by LPS, indicating that $\mathrm{MOK}$ extract inhibited $\mathrm{PGE}_{2}$ production by downregulating the transcription of COX-2 in activated macrophages.

Effect of MOK extract on the LPS-induced production of pro-inflammatory cytokines. To better understand the inhibitory effects of MOK extract on inflammation, mRNA expression of pro-inflammatory cytokines (IL-6, IL-1 $\beta$ and TNF- $\alpha$ ) was investigated via RT-PCR in RAW 264.7 cells stimulated by LPS. The expression of pro-inflammatory cytokines (IL-6, IL-1 $\beta$ and TNF- $\alpha$ ) at the mRNA level exhibited a statistically significant increase $(\mathrm{P}<0.05, \mathrm{P}<0.01$ and $\mathrm{P}<0.05$, respectively) following stimulation of the cells by LPS. Treatment with MOK extract was associated with inhibition of LPS-induced mRNA expression of IL-6, IL- $1 \beta$ and TNF- $\alpha$ in RAW 264.7 cells (Fig. 4A); a statistically significant decrease $(\mathrm{P}<0.05)$ in the expression of these mRNAs at a concentration of $10 \mathrm{mg} / \mathrm{ml} \mathrm{MOK} \mathrm{(Fig.} \mathrm{4B)} \mathrm{was} \mathrm{observed,} \mathrm{indicating} \mathrm{that}$ 


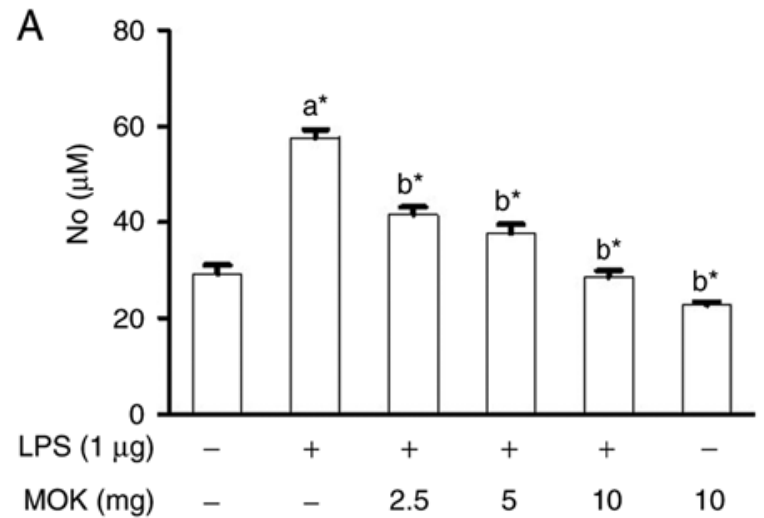

B
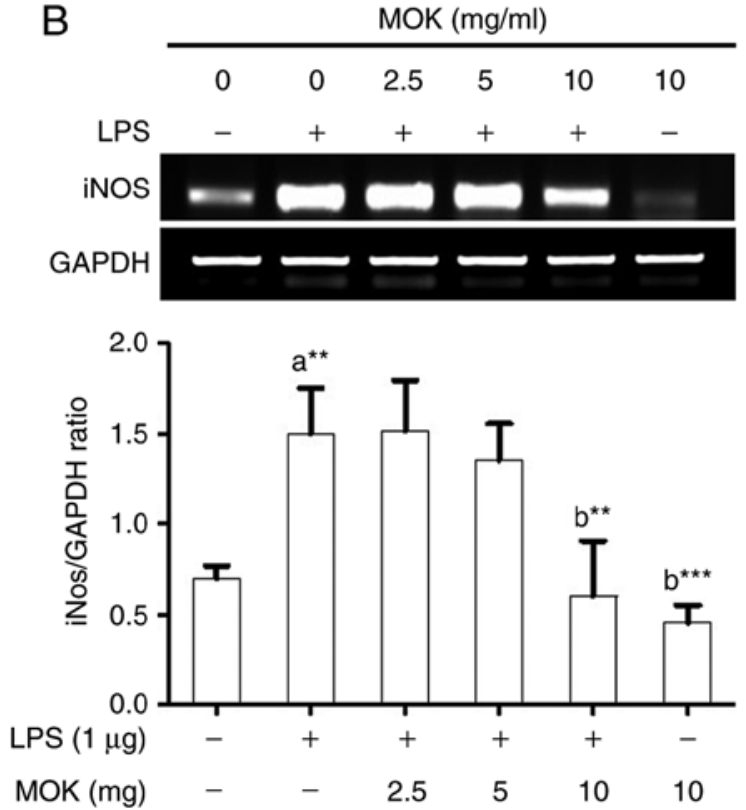

C
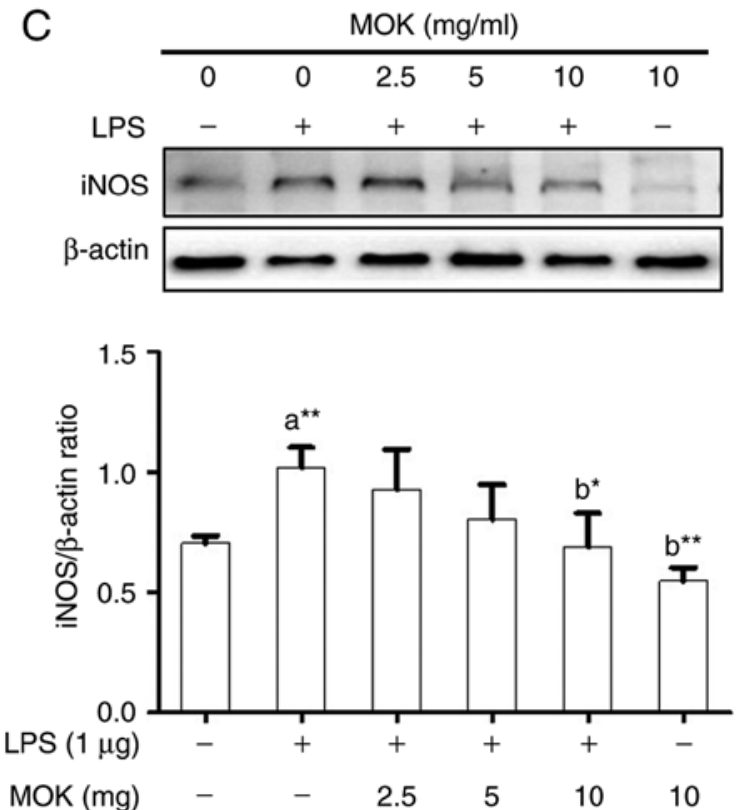

Figure 2. Effects of MOK extract on NO production and iNOS expression in RAW 264.7 cells stimulated by LPS. (A) After treatment with the indicated MOK extract concentrations for $30 \mathrm{~min}$, cells were stimulated for $24 \mathrm{~h}$ with LPS $(1 \mu \mathrm{g} / \mathrm{ml})$. Griess reaction was used to measure NO concentrations in the culture media. Data represent means \pm standard error of the mean of three independent experiments. ${ }^{*} \mathrm{P}<0.05,{ }^{* *} \mathrm{P}<0.01$ and ${ }^{* * * *} \mathrm{P}<0.001$ vs. 1 st bar, untreated control cells (a) or 2nd bar, cells treated with LPS only (b). (B) After treatment with MOK extract for 30 min, cells were stimulated with LPS for an additional 5 h. Total RNA was isolated, and then RT-PCR was used to measure the mRNA levels of iNOS with GAPDH expression as an internal control. (C) After treatment with MOK extract for $30 \mathrm{~min}$, cells were stimulated with LPS for an additional $24 \mathrm{~h}$. The cell lysates were extracted and western blotting was used to analyze iNOS protein levels with $\beta$-actin expression as an internal control. Mean densitometric values of the three independent experiments were analyzed and are expressed as bar charts. NO, nitric oxide; iNOS, inducible nitric oxide synthase; LPS, lipopolysaccharide; RT-PCR, reverse transcription-polymerase chain reaction; GAPDH, glyceraldehyde 3-phosphate dehydrogenase.

MOK extract inhibits the synthesis of pro-inflammatory cytokines in activated macrophages.

Effect of MOK extract on the MAPK/NF- $\kappa B$ pathway. To confirm the effects of MOK extract on inflammatory signaling in RAW 264.7 cells, the phosphorylation of ERK1/2, JNK and p38 MAPK, and the expression of NF- $\mathrm{B}$ p 65, were investigated by western blot analysis. Phosphorylation of MAPK (ERK1/2, JNK and p38) exhibited a statistically significant increase $(\mathrm{P}<0.01, \mathrm{P}<0.001$ and $\mathrm{P}<0.01$, respectively) following stimulation of the cells by LPS. Treatment with $5 \mathrm{mg} / \mathrm{ml}$ $(\mathrm{P}<0.05, \mathrm{P}<0.01$ and $\mathrm{P}<0.001$, respectively) and $10 \mathrm{mg} / \mathrm{ml}$ MOK extract $(\mathrm{P}<0.01, \mathrm{P}<0.001$ and $\mathrm{P}<0.001$, respectively) was associated with a statistically significant inhibition of phosphorylation of MAPK (ERK1/2, JNK and p38) in RAW 264.7 cells stimulated by LPS (Fig. 5). NF- $\mathrm{B}$ p 65 nuclear expression statistically significantly increased $(\mathrm{P}<0.05)$ following stimulation of the cells by LPS (Fig. 6). Additionally, MOK extract treatment at concentrations of $2.5,5$ and $10 \mathrm{mg} / \mathrm{ml}$ resulted in a significant decrease $(\mathrm{P}<0.05, \mathrm{P}<0.01$ and $\mathrm{P}<0.01$, respectively) of NF- $\kappa \mathrm{B}$ p 65 nuclear expression in LPS-stimulated cells (Fig. 6A and B); this inhibitory effect of MOK was also observed via immunohistochemistry (Fig. 6C). Therefore, it was demonstrated that MOK treatment inhibited nuclear trans-

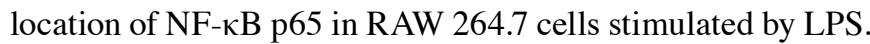
In addition, the results indicated that the inhibitory effects of MOK extract on the production of pro-inflammatory factors are mediated by inhibition of the MAPK/NF- $\kappa \mathrm{B}$ pathway in activated macrophages.

Effect of MOK extract on oxidative damage. Next, the inhibitory effect of MOK extract on oxidative damage was 


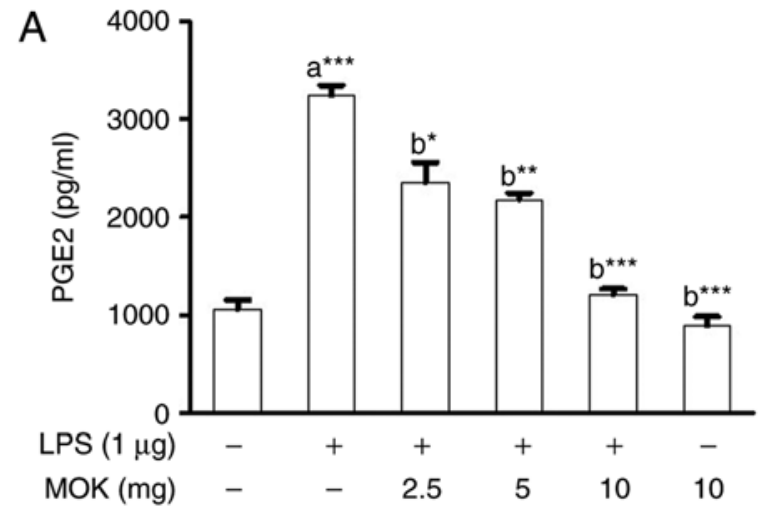

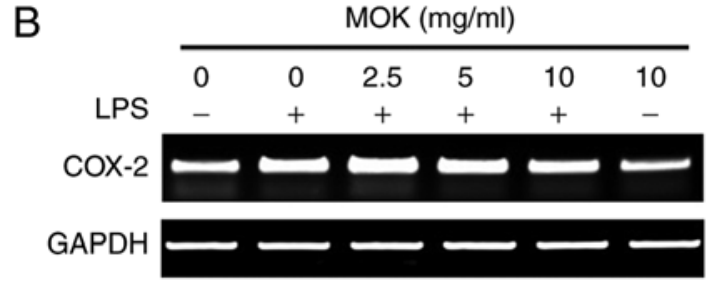

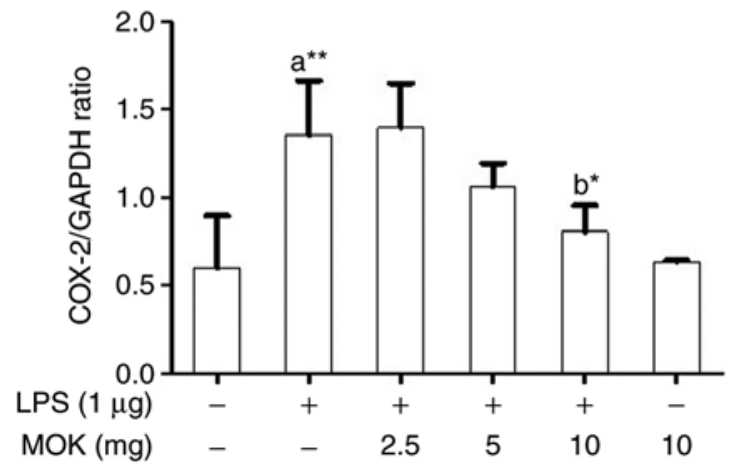

C

\begin{tabular}{|c|c|c|c|c|c|c|}
\hline & \multicolumn{6}{|c|}{ MOK (mg/ml) } \\
\hline & 0 & 0 & 2.5 & 5 & 10 & 10 \\
\hline LPS & - & + & + & + & + & - \\
\hline cox-2 & $\mathrm{O}$ & $E$ & $\mathrm{Ca}$ & 0. & $a=$ & 64 \\
\hline
\end{tabular}

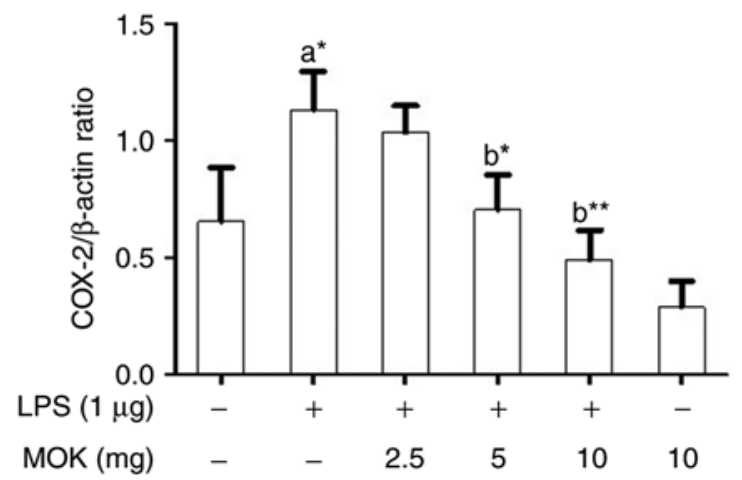

Figure 3. Effects of MOK extract on the production of $\mathrm{PGE}_{2}$ and expression of COX-2 in RAW 264.7 cells stimulated by LPS. (A) After treatment with various concentrations of MOK extract for $30 \mathrm{~min}$, cells were then stimulated with LPS. At $16 \mathrm{~h}$, culture media were collected and measured by an enzyme immunoassay for $\mathrm{PGE}_{2}$ concentration. Data represent means \pm standard error of the mean of three independent experiments. ${ }^{*} \mathrm{P}<0.05,{ }^{* *} \mathrm{P}<0.01$ and ${ }^{* * * *} \mathrm{P}<0.001$ vs. 1st bar, untreated control cells (a) or 2nd bar, cells treated with LPS only (b). (B) After treatment with MOK extract for 30 min, cells were stimulated with LPS for an additional $5 \mathrm{~h}$. RT-PCR was used to measure the mRNA levels of COX-2 with GAPDH expression as an internal control. (C) After treatment with MOK extract for $30 \mathrm{~min}$, cells were stimulated with LPS for an additional $24 \mathrm{~h}$. Western blotting was used to analyze the protein level of COX-2 in total cell lysates with $\beta$-actin as an internal control. Mean densitometric values of the three independent experiments were analyzed and are expressed as bar charts. $\mathrm{PGE}_{2}$, prostaglandin $\mathrm{E}_{2}$; COX, cyclooxygenase; LPS, lipopolysaccharide; RT-PCR, reverse transcription-polymerase chain reaction; GAPDH, glyceraldehyde 3-phosphate dehydrogenase.

investigated by measuring ROS production and antioxidant enzyme expression in RAW 264.7 cells stimulated by LPS. Following stimulation of the cells by LPS, ROS production exhibited a significant increase (Fig. 7A), along with a significant decrease in antioxidant enzyme expression, except HO-1 production (Fig. 7B and C). Treatment by 5 or $10 \mathrm{mg} / \mathrm{ml} \mathrm{MOK}$ extract achieved a statistically significant decrease $(\mathrm{P}<0.05$ and $\mathrm{P}<0.001$, respectively) in the production of ROS in LPS-stimulated cells in a concentration-dependent manner (Fig. 7A). Additionally, with concentrations of MOK extract of $2.5,5$ and $10 \mathrm{mg} / \mathrm{ml}$, there was a statistically significant increase in the mRNA expression of HO-1 $(\mathrm{P}<0.05, \mathrm{P}<0.05$ and $\mathrm{P}<0.01$, respectively) and MnSOD $(\mathrm{P}<0.01, \mathrm{P}<0.05$ and $\mathrm{P}<0.01$, respectively), as well as an increase in the expression of SOD2 ( $\mathrm{P}<0.01, \mathrm{P}<0.01$ and $\mathrm{P}<0.05$, respectively) and CAT $(\mathrm{P}<0.05$ for $5 \mathrm{mg} / \mathrm{ml}$ and $\mathrm{P}<0.01$ for $10 \mathrm{mg} / \mathrm{ml}$ ) proteins in $\mathrm{RAW}$ 264.7 cells stimulated by LPS (Fig. 7B and C). These results indicate that MOK extract may prevent oxidative damage by inhibiting ROS production and activating antioxidant enzymes in activated macrophages.

\section{Discussion}

Pharmacopuncture is a frequently used practice in clinical TKM, as it acts faster and is considered to be more effective compared with orally administered medicines. MOK is a polyherbal pharmacopuncture medicine that consists of ten herbs (Table I) and is frequently used in clinical practice for the treatment of heart and thyroid diseases. Although scientific evidence regarding the therapeutic aspects of MOK is lacking, it is expected that the clinical applications of MOK will be justified based on efficacy studies of the MOK constituents.

RAW264.7 is a functional macrophage line transformed by Abelson leukemia virus (18) and requires LPS for full 
A

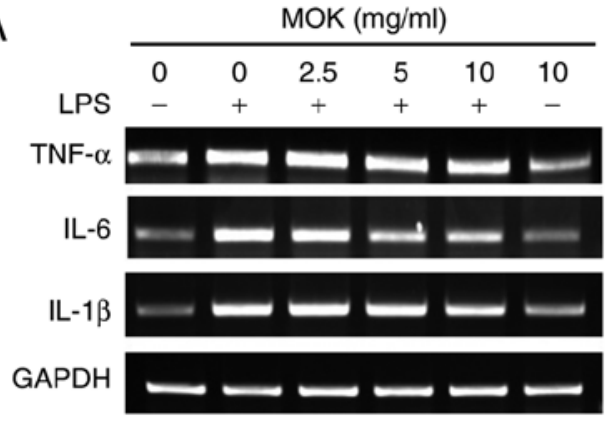

B

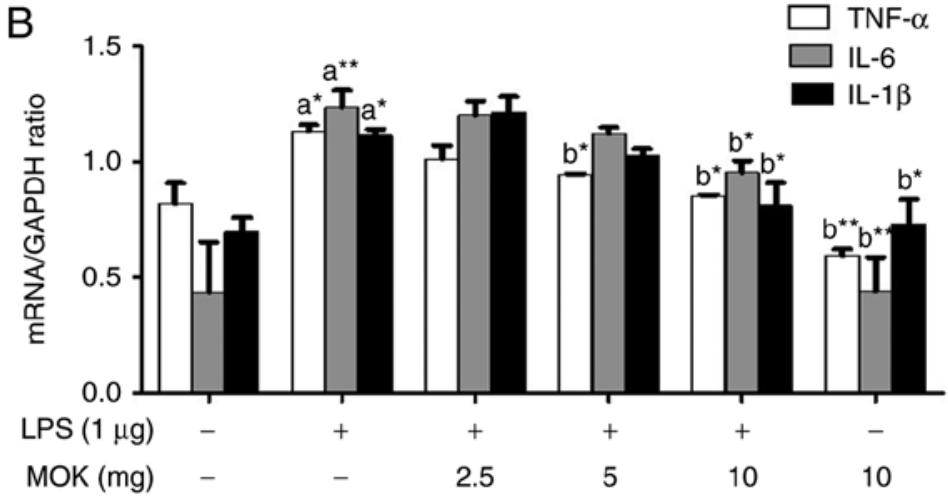

Figure 4. Effects of MOK extract on production of pro-inflammatory cytokines induced by LPS in RAW 264.7 cells. Cells were incubated with MOK extract for $6 \mathrm{~h}$ with or without LPS. (A) RT-PCR was used to measure the mRNA level of each cytokine (TNF- $\alpha$, IL-1 $\beta$ and IL-6) with GAPDH as an internal control (ratios are in relation to GAPDH). (B) Data represent means \pm standard error of the mean of three independent experiments. ${ }^{*} \mathrm{P}<0.05$ and ${ }^{* *} \mathrm{P}<0.01$ vs. 1 st bar, untreated control cells (a) or 2nd bar, cells treated with LPS only (b). Mean densitometric values of the three independent experiments were analyzed and are expressed as bar charts. LPS, lipopolysaccharide; RT-PCR, reverse transcription-polymerase chain reaction; TNF, tumor necrosis factor; IL, interleukin; GAPDH, glyceraldehyde 3-phosphate dehydrogenase.

A
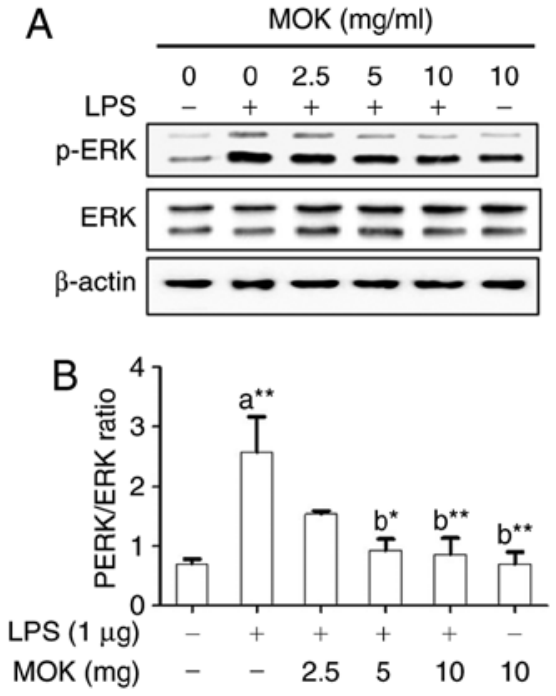
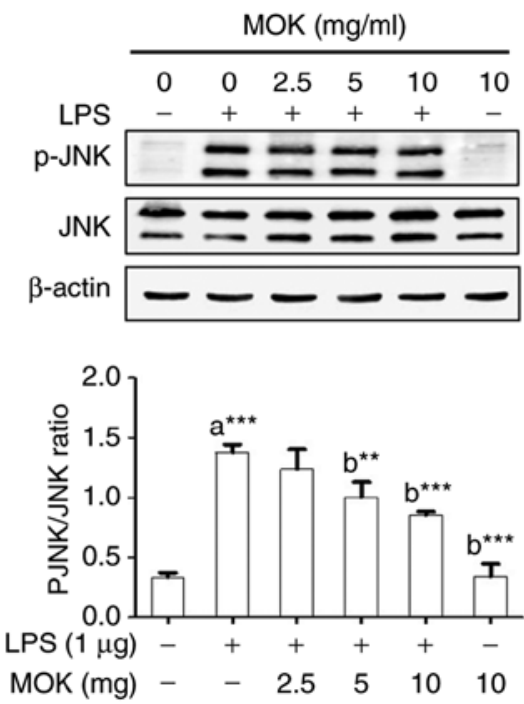
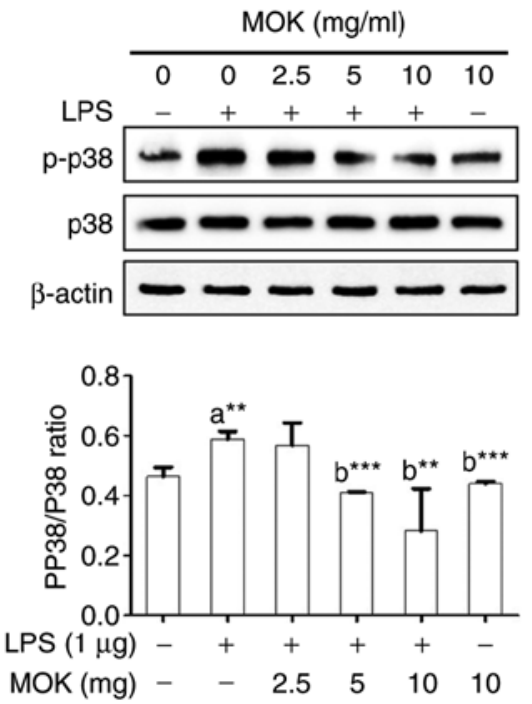

Figure 5. Effects of MOK extract on phosphorylation of MAPKs induced by LPS in RAW 264.7 cells. After treatment with the indicated MOK extract concentrations for $30 \mathrm{~min}$, cells were stimulated for $5 \mathrm{~min}$ with LPS (for ERK) or for 15 min with LPS (for JNK and p38 MAPK). (A) The cellular proteins were used to detect the phosphorylated or total forms of the MAPK molecules ERK1/2, JNK and p38 MAPK with $\beta$-actin as the housekeeping control protein. (B) Data represent means \pm standard error of the mean of three independent experiments. ${ }^{*} \mathrm{P}<0.05,{ }^{* *} \mathrm{P}<0.01$ and ${ }^{* * * *} \mathrm{P}<0.001$ vs. 1 st bar, untreated control cells (a) or 2 nd bar, cells treated with LPS only (b). Mean densitometric values of the three independent experiments were analyzed and are expressed as bar charts. MAPK, mitogen-activated protein kinase; LPS, lipopolysaccharide; ERK, extracellular signal-regulated kinase; JNK, c-Jun N-terminal kinase.

activation. RAW264.7 cells are commonly used to study the anti-inflammatory properties of drugs. In the present study, in order to investigate the effects of MOK extract on inflammatory and oxidative responses, RAW264.7 cells were stimulated with LPS $(1 \mu \mathrm{g} / \mathrm{ml})$. We first determined the non-toxic concentrations of MOK extract with or without LPS in RAW264.7 macrophages using a WST viability assay. The decrease of RAW264.7 cell viability following LPS stimulation due to the release of inflammatory substances, which may act as cytotoxic agents, has been previously demonstrated, but an increase in cell viability (19) or little change in cell viability (20-23) have also been reported. However, in our cell viability assay, LPS $(1 \mu \mathrm{g} / \mathrm{ml})$ stimulation of RAW263.7 cells was not associated with a decrease in their viability, similar to non-treated cells or cells treated with MOK alone.
MOK did not decreased cell viability at $10 \mathrm{mg} / \mathrm{ml}$; therefore, MOK extract at 2.5,5 and $10 \mathrm{mg} / \mathrm{ml}$ was used for the efficacy study. MOK extract is applied in pharmacopuncture therapy at concentrations in the range of $0.2 \mathrm{ml}(10.62 \mathrm{mg})$ to $0.4 \mathrm{ml}(21.24 \mathrm{mg})$ that are known to be safe (10) for patients with various conditions, such as Hwa-Byeong (11), tension headache (12), functional dyspepsia (13) and herpes zoster (24).

Among the ten MOK constituent herbs, Moschus berezovskii (Moschus), Bos taurus (Bovis Calculus) and Ursus arctos (Ursi Fel) comprise the main active components. Specifically, M. berezovskii is a representative orifice-opening medicine used in unconscious patients and $U$. arctos, B. taurus, Scutellaria baicalensis, Phellodendron amurense, Pulsatilla koreana and Sophora tonkinensis act as heatclearing medicines for patients with fever. Aucklandia lappa 


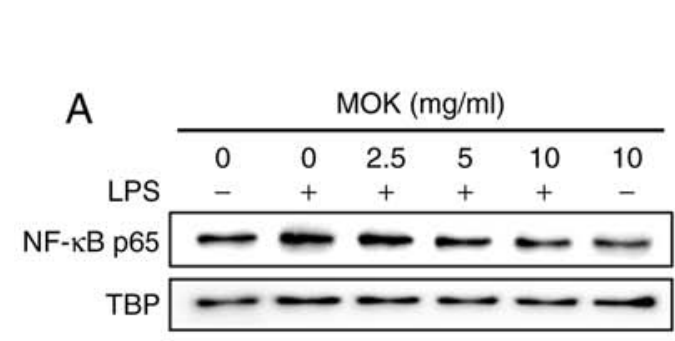

C

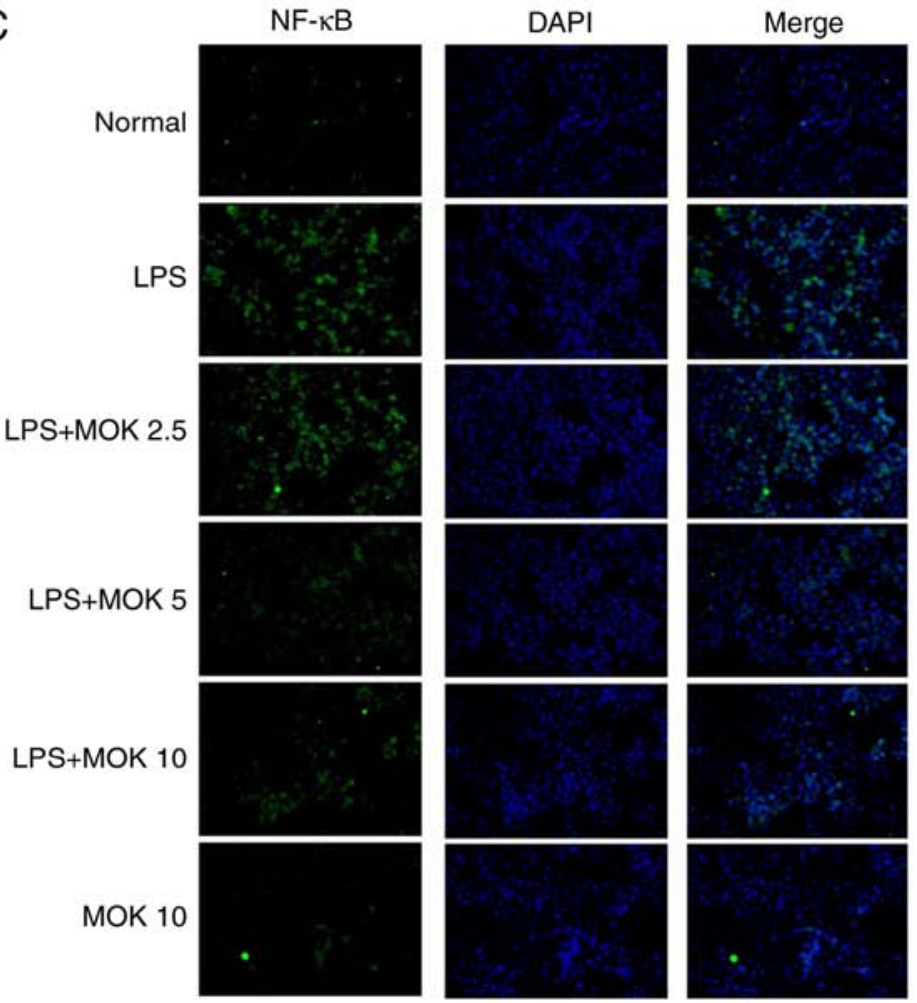

Figure 6. Effects of MOK extract on the expression of NF- $\mathrm{KB}$ induced by LPS in RAW 264.7 cells. Graded concentrations of MOK extract were used to pretreat cells for $30 \mathrm{~min}$, followed by stimulation for $30 \mathrm{~min}$ with LPS. RAW 264.7 cells were harvested, and then the nuclei and cytosol were isolated (A and B) Western blot analysis was used to detect the expression of NF-кB p65 in the nuclei with TATA-binding protein (TBP) as an internal control. Data represent means \pm standard error of the mean of three independent experiments. ${ }^{*} \mathrm{P}<0.05$ and ${ }^{* *} \mathrm{P}<0.01$ vs. 1st bar, untreated control cells (A) or $2 \mathrm{nd}$ bar, cells treated with LPS only (b). Mean densitometric values of the three independent experiments were analyzed and are expressed as bar charts. (C) The translocation of NF- $\mathrm{kB}$ to the nucleus from the cytoplasm was observed by fluorescence microscopy after staining with anti-NF- $\mathrm{B}$ p65 antibody (green, Alexa Fluor

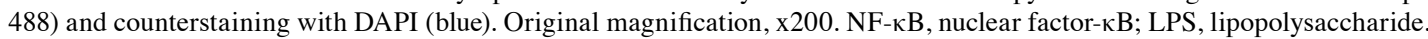

and Aquilaria agallocha are medicines regulating qi, whereas Hominis plancenta is a medicine for tonifying and replenishing. Notably, these ten herbs have individually been reported to have anti-inflammatory and antioxidant properties (25-32). Additionally, in our previous high-performance liquid chromatography analysis of MOK extract, we detected several compounds, such as bilirubin, ursodeoxycholic acid, baicalein and muscone, that were also reported to have anti-inflammatory and antioxidant properties (15). Therefore, various pharmaceutical effects of MOK extract in pharmacopuncture therapy may be predicted based on the studies on the individual effects of MOK components in vitro and in vivo. Furthermore, in the present study, MOK was found to exert anti-inflammatory and antioxidant effects on RAW 264.7 macrophages stimulated by LPS by downregulating inflammatory mediators and upregulating antioxidant enzymes. Unavoidable noxious stimuli that adversely affect normal tissue function induce inflammation as a protective response (33). Inflammation, as one of several immune responses against infection, is implicated in various human diseases, including cancer, neurological disorders, metabolic syndromes, inflammatory bowel disease, arthritis, cardiovascular and infectious diseases $(34,35)$.

Although inflammatory mediators (NO, iNOS, $\mathrm{PGE}_{2}$ and COX-2) and pro-inflammatory cytokines (TNF- $\alpha$, IL- $1 \beta$ and IL-6) produced by activated macrophages have important functions regarding host survival and tissue repair in the normal state (36), whereas their overproduction contributes to the induction and progression of several inflammatory diseases $(37,38)$. Accordingly, the regulation of inflammatory mediators is recognized as a beneficial therapeutic strategy for inflammatory diseases. The present study demonstrated that MOK extract inhibited $\mathrm{NO}$ and $\mathrm{PGE}_{2}$ production by downregulating the expression of their synthetic enzymes, including iNOS and COX-2, as well as pro-inflammatory cytokines, including IL-6, IL- $1 \beta$ and TNF- $\alpha$, in RAW 264.7 cells stimulated by LPS. We previously reported that MOK extract also inhibits the expression of iNOS, COX-2 and pro-inflammatory cytokines in primary macrophages isolated from the mouse peritoneal cavity (18). These results indicate that MOK extract effectively improves inflammatory conditions, as it can suppress the overproduction of inflammatory mediators by activated macrophages.

Oxidative stress caused by ROS overproduction damages cellular lipids, DNA and proteins, and is implicated in a variety of acute and chronic inflammatory diseases, cardiovascular disease, diabetes, central nervous system disorders, age-related disorders, neurodegenerative disorders and cancer $(39,40)$. Notably, macrophage stimulation by LPS also causes production of ROS $(41,42)$. Cells have two defense systems that react to oxidative stress from exogenous and endogenous sources, with compounds related to the latter including antioxidant enzymes, such as SODs (CuZnSOD and MnSOD), CAT and HO-1 (39). Therefore, the downregulation of ROS expression levels or the upregulation of antioxidant enzyme activity is important 
A

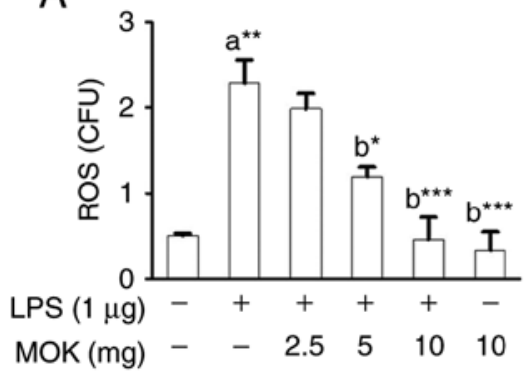

B
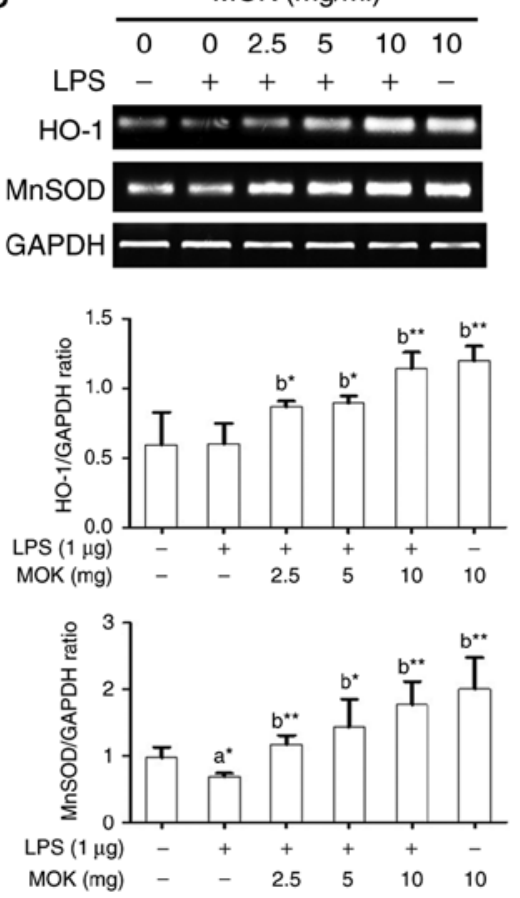

C
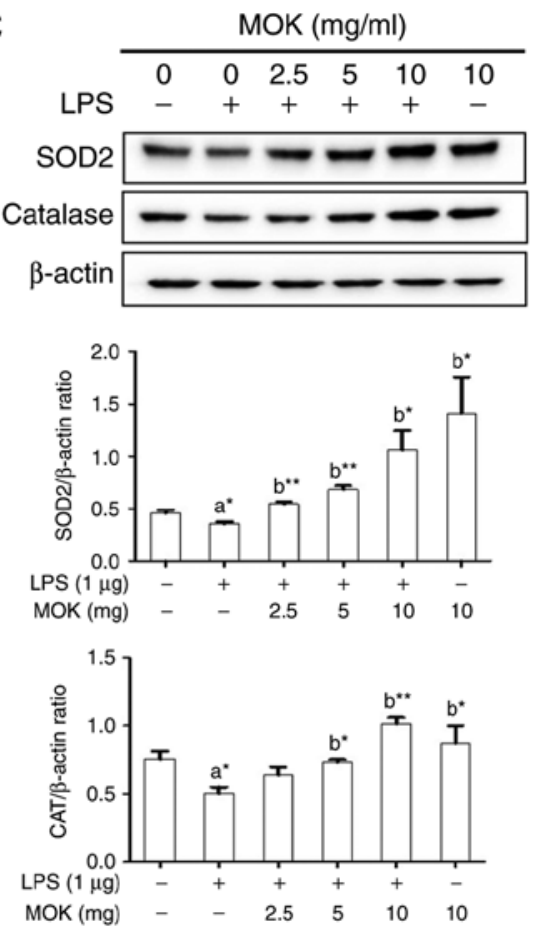

Figure 7. Effects of MOK extract on ROS production and expression of antioxidant genes and proteins (MnSOD, HO-1, SOD2 and CAT) in RAW 264.7 cells stimulated with LPS. (A) After treatment with graded concentrations of MOK extract for $30 \mathrm{~min}$, cells were stimulated for $24 \mathrm{~h}$ with or without LPS Then, the cells were homogenized, and an in vitro ROS/RNS assay kit used to measure ROS levels in RAW 264.7 cells stimulated with LPS. Data represent means \pm standard error of the mean of three independent experiments. ${ }^{*} \mathrm{P}<0.05,{ }^{* *} \mathrm{P}<0.01$ and ${ }^{* * * *} \mathrm{P}<0.001 \mathrm{vs}$. 1st bar, untreated control cells (A) or 2 nd bar, cells treated with LPS only (b). (B) After treatment with MOK extract for $30 \mathrm{~min}$, the cells were stimulated for an additional $5 \mathrm{~h}$ with LPS. RT-PCR was used to measure the mRNA levels of MnSOD and HO-1 with GAPDH expression as an internal control. (C) After treatment with MOK extract for 30 min, the cells were stimulated for an additional $24 \mathrm{~h}$ with LPS. Western blotting was used to analyze the protein levels of SOD2 and CAT in total cell lysates with $\beta$-actin as an internal control. Mean densitometric values of the three independent experiments were analyzed and are expressed as bar charts. ROS, reactive oxygen species; RNS, reactive nitrogen species; LPS, lipopolysaccharide; RT-PCR, reverse transcription-polymerase chain reaction; SOD, superoxide dismutase; HO-1, heme oxygenase-1; CAT, catalase; GAPDH, glyceraldehyde 3-phosphate dehydrogenase.

for the treatment of oxidative damage. In previous studies, it was reported that LPS stimulation induces oxidative stress by increasing ROS production and decreasing the expression of antioxidant enzymes, SOD, MnSOD, HO-1 and the levels of GSH in RAW264.7 macrophages $(43,44)$. In the present study, MOK extract inhibited ROS production by upregulating the expression of SOD and CAT in RAW 264.7 cells stimulated by LPS. These results suggest that MOK exerts antioxidant effects during macrophage activation. Additionally, we also reported that MOK extract inhibited mRNA expression of HO-1 and MnSOD in mouse peritoneal macrophages without LPS stimulation (17).

To elucidate the underlying mechanism responsible for the anti-inflammatory and antioxidant effects of MOK extract, its regulatory effects on the MAPK/NF- $\mathrm{KB}$ inflammatory signaling pathway were investigated in RAW 264.7 cells stimulated by LPS, as the therapeutic effects of several anti-inflammatory agents are associated with inhibition of inflammatory gene expression, which often occurs through blockade of the MAPK/NF- $\kappa B$ pathway in macrophage activation. Antioxidant effects also depend on an increase in antioxidant enzyme expression and a decrease in ROS levels. ERK1/2, JNK and p38 MAPKs along with NF- $\kappa B$ comprise two cellular pathways involved in macrophage-mediated inflammation. Specifically, MAPKs are a family of proteins associated with serine/threonine kinases, which play an important role in cell proliferation and differentiation and cellular responses to cytokines or stress inducers. These are activated by phosphorylation and then induce activation of the transcription factor NF- $\kappa B$. $\mathrm{NF}-\kappa \mathrm{B}$ also plays a key role in the pathogenesis and regulation of inflammatory responses, and its activation can regulate inflammatory cytokines $(40,45,46)$. In the present study, MOK extract inhibited the phosphorylation of ERK1/2, JNK and p38 MAPKs, as well as the nuclear translocation of NF- $\mathrm{KB}$ p65 in RAW 264.7 cells stimulated by LPS. These findings indicate that MOK extract exerts anti-inflammatory effects in activated macrophages by blocking the MAPK/NF- $\kappa \mathrm{B}$ pathway. In a future study, we will consider the application of specific inhibitors, e.g., MAPK inhibitors, to investigate the underlying mechanism in detail.

In conclusion, MOK extract, a pharmacopuncture medicine, inhibited the production of the inflammatory mediators $\mathrm{NO}$ and $\mathrm{PGE}_{2}$ in RAW 264.7 cells stimulated by LPS by downregulating their synthetic enzymes, iNOS and COX. The expression of pro-inflammatory cytokines, such as IL-6, IL-1 $\beta$ and TNF- $\alpha$, was also inhibited. In addition, MOK extract inhibited the phosphorylation of ERK1/2, JNK and p38 MAPKs and the nuclear translocation of NF- $\kappa B$ p65 in RAW 264.7 cells stimulated by LPS. Moreover, MOK extract decreased ROS production by inducing the expression of the antioxidant enzymes MnSOD and CAT in RAW 264.7 cells stimulated by LPS. These results indicate that MOK exerts 
anti-inflammatory and antioxidant effects in activated macrophages, and it may be useful for the treatment of inflammatory conditions as a pharmacopuncture medicine.

\section{Acknowledgements}

Not applicable.

\section{Funding}

This study was supported by the National Research Foundation of Korea (NRF), funded by the Korean government (MSIT) (grant no. NRF-2017R1C1B5076224).

\section{Authors' contributions}

JHH, HWJ and YKP made substantial contributions to the conception and design of the present study; JHH, JNM and JHP performed the experiments for data acquisition; JHH, JNM and HWJ performed the statistical analysis; JHH and HWJ interpreted the experimental results and wrote the manuscript; $\mathrm{JHH}$, HWJ, JHP and YKP revised the manuscript. The final version of the manuscript was read and approved by all authors.

\section{Availability of data and materials}

The corresponding author will make available the data generated and analyzed during this study upon reasonable request. All materials used are included in Materials and methods.

\section{Ethics approval and consent to participate}

Not applicable.

\section{Patient consent for publication}

Not applicable.

\section{Competing interests}

The authors declare that they have no competing interests.

\section{References}

1. Liu Z, Tang L, Zou P, Zhang Y, Wang Z, Fang Q, Jiang L, Chen G, $\mathrm{Xu} Z$, Zhang $\mathrm{H}$ and Liang G: Synthesis and biological evaluation of allylated and prenylated mono-carbonyl analogs of curcumin as anti-inflammatory agents. Eur J Med Chem 74: 671-682, 2014.

2. Mittal M, Siddiqui MR, Tran K, Reddy SP and Malik AB: Reactive oxygen species in inflammation and tissue injury. Antioxid Redox Signal 20: 1126-1167, 2014.

3. Zhang L and Wang CC: Inflammatory response of macrophages in infection. Hepastobiliary Pancreat Dis Int 13: 138-152, 2014.

4. Cho SY, Yang SB, Shin HS, Lee SH, Koh JS, Kwon S, Jung WS, Moon SK, Park JM, Ko CN and Park SU: Anti-inflammatory and immune regulatory effects of acupuncture after craniotomy: Study protocol for a parallel-group randomized controlled trial. Trials 18: 481, 2017.

5. Zijlstra FJ, van den Berg-de Lange I, Huygen FJ and Klein J: Anti-inflammatory actions of acupuncture. Mediators Inflamm 12: 59-69, 2003

6. Lisboa MR, Gondim DV, Ervolino E, Vale ML, Frota NP, Nunes NL, Mariguela VC, Taba M Jr, Messora MR and Furlaneto FA: Effects of electroacupuncture on experimental periodontitis in rats. J Periodontol 86:801-811, 2015.
7. McDonald JL, Cripps AW, Smith PK, Smith CA, Xue CC and Golianu B: The anti-inflammatory effects of acupuncture and their relevance to allergic rhinitis: A narrative review and proposed model. Evid Based Complement Alternat Med 2013: 591796, 2013.

8. Song Q, Hu S, Wang H, Lv Y, Shi X, Sheng Z and Sheng W: Electroacupuncturing at Zusanli point (ST36) attenuates pro-inflammatory cytokine release and organ dysfunction by activating cholinergic anti-inflammatory pathway in rat with endotoxin challenge. Afr J Tradit Complement Altern Med 11: 469-474, 2014.

9. Wei Y, Dong M, Zhang H, Lv Y, Liu J, Wei K, Luo Q, Sun J, Liu F, Xu F and Dong J: Acupuncture attenuated inflammation and inhibited Th17 and treg activity in experimental asthma. Evid Based Complement Alternat Med 2015: 340126, 2015.

10. Jung C, Jung JH and Lee MS: A Clinical Study of Immune Pharmacopuncturology. Kyungrak Medical Publishing Co., Chungnam, 2011 (In Korean).

11. Hwang JH: A case report of Hwa-byeong with MOK herbal acupuncture therapy. J Immuno-Pharmacopuncture 2: 43-55, 2013 (In Korean).

12. Ha TD and Jung C: A case report on severe tension-type headache treated with pharmacopuncture (Yakchim). J ImmunoPharmacopuncture 5: 37-45, 2016 (In Korean).

13. Kim MJ, Kim SK, Ko SJ and Park JW: A case study of MOK and V Yakchim on functional dyspepsia. J ImmunoPharmacopuncture 3: 41-49, 2014 (In Korean).

14. Kim HJ, Gwan R, Han JW, Jung C and Park KH: Analysis of physioactivities on MOK Yakchim. J Immuno-Pharmacopuncture 2: 17-25, 2013 (In Korean).

15. Hwang JH, Kang SY, Kang AN, Jung HW, Jung C, Jeong JH and Park YK: MOK, a pharmacopuncture medicine, regulates thyroid dysfunction in L-thyroxin-induced hyperthyroidism in rats through the regulation of oxidation and the TRPV1 ion channel. BMC Complement Altern Med 17: 535, 2017.

16. Hwang JH, Jung HW, Kang SY, Kang AN, Ma JN, Meng XL, Hwang MS and Park YK: Therapeutic effects of acupuncture with MOK, a polyherbal medicine, on PTU-induced hypothyroidism in rats. Exp Ther Med 16: 310-320, 2018.

17. Hwang JH, Hwang MS and Park YK: MOK, a pharmacopuncture medicine, reduces inflammatory response through inhibiting the proinflammatory cytokine production in LPS-stimulated mouse peritoneal macrophages. J Acupunct Res 34: 11-21, 2017.

18. Raschke WC, Baird S, RalpH P and Nakoinz I: Functional macrophage cell lines transformed by Abelson leukemia virus. Cell 15: 261-267,1978.

19. Zhang X, Xiong H and Liu L: Effects of taraxasterol on inflammatory responses in lipopolysaccharide-induced RAW 264.7 macrophages. J Ethnopharmacol 141: 206-211, 2012.

20. Choi HS, Seo HS, Kim SR, Choi YK, Shin YC and Ko SG: Anti-inflammatory and anti-proliferative effect of herbal medicines (APR) in RAW264.7 cells. Mol Med Rep 9: 1569-1574, 2014.

21. Li T, Gao D, Du M, Cheng X and Mao X: Casein glycomacropeptide hydrolysates inhibit $\mathrm{PGE}_{2}$ production and COX2 expression in LPS-stimulated RAW264.7 macrophage cells via Akt mediated NF- $\kappa$ B and MAPK pathways. Food Funct 9: 2524-2532, 2018.

22. Yang X, Kang MC, Li Y, Kim EA, Kang SM and Jeon YJ: Anti-inflammatory activity of questinol isolated from marine-derived fungus Eurotium amstelodami in lipopolysaccharide-stimulated RAW 264.7 macrophages. J Microbiol. Biotechnol, 24: 1346-1353, 2014.

23. Kim HJ, Tsoyi K, Heo JM, Kang YJ, Park MK, Lee YS, Lee JH, Seo HG, Choi HS and Chang KC: Regulation of lipopolysaccharide-induced inducible nitric-oxide synthase expression through the nuclear factor- $\kappa \mathrm{B}$ pathway and interferon- $\beta /$ tyrosine kinase $2 /$ Janus tyrosine kinase 2-signal transducer and activator of transcription-1 signaling cascades by 2-naphthylethyl-6,7-dihydroxy-1, 2, 3, 4-tetrahydroisoquinoline (THI 53), a new synthetic isoquinoline alkaloid. J Pharmacol Exp Ther 320: 782-789, 2007.

24. Gong HM, Jun SA, Lee HJ and Kim JS: A case report of Herpes zoster patient treated with additional CS, V pharmacopuncture. J Immuno-Pharmacopuncture 1: 27-36, 2016.

25. De D, Datta Chakraborty P, Mitra J, Sharma K, Mandal S, Das A, Chakrabarti S and Bhattacharyya D: Ubiquitin-like protein from human placental extract exhibits collagenase activity. PLoS One 8: e59585, 2013.

26. Feng Y, Siu K, Wang N, Ng KM, Tsao SW, Nagamatsu T and Tong Y: Bear bile: Dilemma of traditional medicinal use and animal protection. J Ethnobiol Ethnomed 5: 2, 2009. 
27. Jang SY, Park JW, Bu Y, Kang JO and Kim J: Protective effects of hominis placenta hydrolysates on radiation enteropathy in mice. Nat Prod Res 25: 1988-1992, 2011.

28. Li X, Xu Y, Zhang C, Deng L, Chang M, Yu Z and Liu D: Protective effect of calculus bovis sativus on dextran sulphate sodium-induced uicerative colitis in mice. Evid Based Complement Alternat Med 2015: 469506, 2015.

29. The National College of Oriental Medicine Herbology Classroom: Herbology. Youngrimsa, Seoul, 2016 (In Korean).

30. Park SY, Phark S, Lee M, Lim JY and Sul D: Anti-oxidative and anti-inflammatory activities of placental extracts in benzo[a] pyrene-exposed rats. Placenta 31: 873-879, 2010.

31. Park JY, Lee J, Jeong M, Min S, Kim SY, Lee H, Lim Y and Park HJ: Effect of Hominis Placenta on cutaneous wound healing in normal and diabetic mice. Nutr Res Pract 8: 404-409, 2014.

32. Thevis M, Schänzer W, Geyer H, Thieme D, Grosse J, Rautenberg C, Flenker U, Beuck S, Thomas A, Holland R and Dvorak J: Traditional Chinese medicine and sports drug testing: Identification of natural steroid administration in doping control urine samples resulting from musk (pod) extracts. Br J Sports Med 47: 109-114, 2013.

33. Okin D and Medzhitov R: Evolution of inflammatory diseases Curr Biol 22: R733-R740, 2012.

34. Monaco C, Andreakos E, Kiriakidis S, Feldmann M and Paleolog E: T-cell-mediated signalling in immune, inflammatory and angiogenic processes: the cascade of events leading to inflammatory diseases. Curr Drug Targets Inflamm Allergy 3: 35-42, 2004

35. Yamamoto $Y$ and Gaynor RB: IkappaB kinases: Key regulators of the NF-kappaB pathway. Trends Biochem Sci 29: 72-79, 2004

36. Adib-Conquy M, Scott-Algara D, Cavaillon JM and SouzaFonseca-Guimaraes F: TLR-mediated activation of NK cells and their role in bacterial/viral immune responses in mammals. Immunol Cell Biol 92: 256-262, 2014.

37. Korhonen R, Lahti A, Kankaanranta H and Moilanen E: Nitric oxide production and signaling in inflammation. Curr Drug Targets Inflamm Allergy 4: 471-479, 2005.
38. Sweet MJ and Hume DA: Endotoxin signal transduction in macrophages. J Leukoc Biol 60: 8-26, 1996.

39. Davies KJ: Oxidative stress: The paradox of aerobic life. Biochem Soc Symp 61: 1-31, 1995.

40. Thalhamer T, McGrath MA and Harnett MM: MAPKs and their relevance to arthritis and inflammation. Rheumatol (Oxford) 47: 409-414, 2008.

41. Chang LY, Wan HC, Lai YL, Chou IC, Chen YT and Hung SL: Areca nut extracts increased the expression of cyclooxygenase-2, prostaglandin $\mathrm{E}_{2}$ and interleukin-1 $\alpha$ in human immune cells via oxidative stress. Arch Oral Biol 58: 1523-1531, 2013.

42. Satoh M, Minami Y, Takahashi Y and Nakamura M: Immune modulation: Role of theinflammatory cytokine cascade in the failing human heart. Curr Heart Fail Rep 5: 69-74, 2008.

43. Wang L, Xu Ml, Liu J, Wang Y, Hu JH and Wang MH: Sonchus asper extract inhibits 7 macrophages. Nutr Res Pract 9: 579-585, 2015.

44. Jin Y, Yang J, Lin L, Lin Y and Zheng C: The attenuation of scutellariae radix extract on oxidative stress for colon injury in lipopolysaccharide-induced RAW264.7 Cell and 2,4,6-trinitrobenzene sulfonic acid-induced ulcerative colitis rats. Pharmacogn Mag 12: 153-159, 2016.

45. Broom OJ, Widjaya B, Troelsen J, Olsen J and Nielsen $\mathrm{OH}$ Mitogen activated protein kinases: A role in inflammatory bowel disease? Clin Exp Immunol 158: 272-280, 2009.

46. Shan J, Fu J, Zhao Z, Kong X, Huang H, Luo L and Yin Z: Chlorogenic acid inhibits lipopolysaccharide-induced cyclooxygenase-2 expression in RAW264.7 cells through suppressing NF-kappaB and JNK/AP-1 activation. Int Immunopharmacol 9: 1042-1048, 2009.

This work is licensed under a Creative Commons Attribution-NonCommercial-NoDerivatives 4.0 International (CC BY-NC-ND 4.0) License. 